\title{
Clinical trials of CAR-T cells in China
}

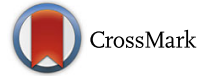

\author{
Bingshan Liu ${ }^{1,2}$, Yongping Song ${ }^{2^{*}}$ and Delong $\operatorname{Liu}^{2^{*}}$ (D)
}

\begin{abstract}
Novel immunotherapeutic agents targeting tumor-site microenvironment are revolutionizing cancer therapy. Chimeric antigen receptor (CAR)-engineered T cells are widely studied for cancer immunotherapy. CD19-specific CAR-T cells, tisagenlecleucel, have been recently approved for clinical application. Ongoing clinical trials are testing CAR designs directed at novel targets involved in hematological and solid malignancies. In addition to trials of single-target CAR-T cells, simultaneous and sequential CAR-T cells are being studied for clinical applications. Multi-target CAR-engineered T cells are also entering clinical trials. T cell receptor-engineered CAR-T and universal CAR-T cells represent new frontiers in CAR-T cell development. In this study, we analyzed the characteristics of CAR constructs and registered clinical trials of CAR-T cells in China and provided a quick glimpse of the landscape of CAR-T studies in China.
\end{abstract}

\section{Background}

Novel immunotherapeutic agents targeting CTLA-4, programmed cell death-1 protein receptor (PD-1), and the ligand PD-L1 are revolutionizing cancer therapy [1-7]. Cancer immunotherapy by re-igniting $\mathrm{T}$ cells through blocking PD-1 and PD-L1 is highly potent in a variety of malignancies [8-12]. Allogeneic hematopoietic stem cell transplantation has been proven to be a curative immunotherapy for leukemia though with significant toxicities [13-18]. Autologous T cells with re-engineered chimeric antigen receptors (CAR-T) have been successfully used for leukemia and lymphoma without graft-vs-host diseases [19-25]. The first such product, tisagenlecleucel, has recently been approved for clinical therapy of refractory $B$ cell acute lymphoblastic lymphoma (ALL). More and more clinical trials of CAR-T cells are being done throughout the world [26-38].

In recent years, more and more clinical trials from China are being done and registered in ClinicalTrials.gov. CAR-T cells have become a major source of cellular immunotherapy in China. This study summarized the CAR$\mathrm{T}$ clinical trials being conducted in China and provided a quick glimpse of the landscape of CAR-T studies in China.

\section{Methods}

We searched ClinicalTrials.gov using keywords "CAR T," "CAR-T," "chimeric antigen receptor," "adoptive therapy,"

\footnotetext{
*Correspondence: songyongping001@163.com; delong_liu@nymc.edu ${ }^{2}$ Henan Cancer Hospital and The Affiliated Cancer Hospital of Zhengzhou University, 127 Dongming Road, Zhengzhou 450008, China

Full list of author information is available at the end of the article
}

"third generation chimeric," and "fourth generation chimeric"; country: China. All relevant trials registered at the ClinicalTrials.gov prior to July 18, 2017, were included in the analysis. One trial was excluded (NCT03121625) because the target antigen was not disclosed. A search of the PubMed database was also done to include those trials and cases that have been published.

\section{Results \\ Distribution of CAR-T trials in China}

Currently, there are 121 trials reported and/or registered at ClinicalTrials.gov from China (Table 1). The trials are mainly carried out in leading hospitals from Beijing, Shanghai, Guangzhou, and Chongqing. CAR-T trials are started in hospitals throughout China. In this study, to avoid duplication of trials that can lead to miscalculation, those trials in Chinese registries were not included. It is possible that the number of institutions carrying out CAR-T trials will increase at a slower pace once regulatory policies are in place. We believe these CAR-T cells should be regulated as drugs [39].

\section{Chimeric antigen receptors, vectors, and co-stimulatory molecules used in the CAR constructs}

$\mathrm{T}$ cell receptors (TCRs) are engineered by incorporating a specific antigen-targeting element and CD3 element to form a completely novel TCR structure, the chimeric antigen receptor (CAR) [35, 40]. In addition, several co-stimulating sequences have been used to facilitate the expansion of the CAR-T cells [41]. CAR-engineered T lymphocytes have been 
Table 1 Distribution of clinical trials with CAR-T cells in China

\begin{tabular}{ll}
\hline Beijing & 30 \\
Shanghai & 22 \\
Guangdong & 20 \\
Chongqing & 15 \\
Jiangsu & 13 \\
Others & 21 \\
\hline
\end{tabular}

in active clinical development to treat patients with advanced leukemia, lymphoma, and solid tumors [42-45].

One of the major hurdles in CAR-targeted cellular therapy has been the limited cell dose due to the lack of adequate in vivo cell expansion. Co-stimulatory signals can enhance immune responses of effector $\mathrm{T}$ cells [46]. Inducible co-stimulatory signal (ICOS), 4-1BB (CD137),

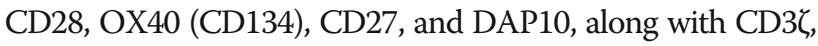
have been investigated [31, 47-50]. Among these, 4-1BB (CD137), CD28, and CD3 $\zeta$ are the most commonly used COS elements in the CARs (Tables 2, 3, and 4) [51, 52].

Most CARs in the CAR-T trials in China are secondgeneration CAR constructs, which have one co-stimulatory signal [41]. A trial of CAR-T cells containing a thirdgeneration CAR construct with both CD28 and CD137 co-stimulatory signals is still recruiting patients with relapsed/refractory ALL (NCT02186860). Fourth-generation CARs have incorporated additional elements in the CAR constructs, such as an inducible caspase- 9 gene element that can lead to self-destruction by apoptosis of the CAR-T cells [53]. A total of 10 trials of CAR-T cells contain a fourthgeneration CAR (Table 5). Among these, five trials are evaluating CARs with an inducible caspase-9 suicide switch.

The recombinant CAR cassette is typically packaged into a pseudo-lentivirus vector which can efficiently incorporate into the genome of $\mathrm{T}$ cells. To date, the lentiviral vector is the most commonly used vector in CAR-T cells. The other vector commonly used is the retroviral vector (Tables 2, 3, and 4).

\section{Antigen targets}

By altering a specific antigen-targeting element, the specificity of the CAR-T cells can be easily re-directed to a specific type of malignancy. This makes the CAR-T cell therapy highly versatile. A number of antigens have been targeted in this way. More and more antigens are being engineered into CAR-T cells, leading to a large repertoire of CAR-T cells that are being explored for the therapy of both solid and hematological malignancies (Tables 3 and 4).

CD19 is the most commonly targeted antigen to date (Table 2). Out of the 121 trials, 57 trials have CD19 as a target. Currently, there are 19 clinical trials in China targeting non-CD19 antigens, including CD20, CD22, CD30, CD33, CD38, CD123, CD138, BCMA, and Lewis Y antigen for hematological malignancies (Table 3). Dual- and multi-specificity CAR-T cells have also been in clinical trials in China.

\section{Current trials on hematological malignancies}

The most common type of diseases in CAR-T trials are $\mathrm{B}$ cell malignancies, including leukemia, lymphoma, and myeloma.

The CD19-targeted autologous CAR-T product, tisagenlecleucel, was recently approved by FDA for therapy of refractory/relapsed $(\mathrm{r} / \mathrm{r}) \mathrm{B}$ cell ALL. In 30 patients including children and adults who received this product, $90 \%$ of them achieved complete remission (CR) [54]. Severe cytokine-release syndrome (CRS) was reported in $27 \%$ of the patients. This product has been in clinical trials for CD19+ B cell malignancies, including CLL, ALL, and lymphoma [21-24, 54, 55]. In a Chinese study (NCT 02813837), 30 patients (5 children and 25 adults) with $\mathrm{r} / \mathrm{r}$ ALL were treated with autologous CD-19 CAR$\mathrm{T}$ cells [56]. In this 2017 report of preliminary results of a seven-center clinical trial, CR was $86 \%$ and severe CRS was seen in $26 \%$ of the patients [56]. Successful outcome has been reported with other CAR-T cells against CD19 antigen in r/r ALL [29, 32, 57-59].

The CD19-specific CAR-T cells, axicabtagene ciloleucel (axi-cel, KTE-C19), have been reported to be safe for treatment of aggressive lymphomas including $\mathrm{r} / \mathrm{r}$ diffuse large cell lymphoma (DLBCL) [25]. In the phase II part of the ZUMA-1 trial, overall response rate (ORR) was $76 \%$ (47\% CR and 29\% PR) at the time of report in the cohort 1 of 51 patients [60]. This product is currently under evaluation by FDA.

CD33 and CD123 are targets on myeloid leukemias. Currently, there are three trials on CAR-T cells targeting CD33 and two trials targeting CD123 antigen in China (Table 3). In the USA, three CAR-T trials targeting CD123 were either terminated (NCT02623582) or suspended (UCART123, NCT02159495, and NCT03190278) at this time.

$\mathrm{B}$ cell maturation antigen (BCMA) is an antigen target on myeloma cells. Currently, three trials on BCMAtargeted CAR-T cells are being done in $\mathrm{r} / \mathrm{r}$ myeloma in China (Table 3). In one of the trials of CAR-T cells targeting BCMA in China, 19 patients with $\mathrm{r} / \mathrm{r}$ multiple myeloma were evaluable and 7 of the patients were followed for more than 6 months at the time of the report [61]. CRS was observed in 14 (74\%) patients. The ORRs were close to $100 \%$ in the evaluable $\mathrm{r} / \mathrm{r}$ myeloma patients. The outcome from the preliminary report was highly encouraging. Complete response was also reported in a case of $\mathrm{r} / \mathrm{r}$ myeloma patient who received autologous CTL019 cells, even though 99.95\% of the myeloma cells were negative for CD19 [38, 62]. It appears therefore that multiple myeloma is highly sensitive to immunotherapy. 
Table 2 Clinical trials of CD19-directed CAR-T cells in China

\begin{tabular}{|c|c|c|c|c|}
\hline Target antigen & Diseases & CAR & Vector & NCT no. \\
\hline CD19 & Leukemia, lymphoma & 4-1BB- CD3乙 & RV & NCT01864889 \\
\hline CD19 & B cell malignancies & CD28, CD137, CD27 & LV & NCT03050190 \\
\hline CD19 & $\mathrm{MCL}$ & 4-1BB-CD3ろ & RV & NCT02081937 \\
\hline CD19 & Leukemia & NA & NA & NCT03142646 \\
\hline CD19 & B cell lymphomas & CD27-CD3Z & LV & NCT02247609 \\
\hline CD19 & Leukemia, lymphoma & NA & NA & NCT02349698 \\
\hline CD19 & Elderly relapsed/refractory B cell ALL & NA & NA & NCT02799550 \\
\hline CD19 & Leukemia, lymphoma & NA & NA & NCT02537977 \\
\hline CD19 & B cell leukemia & NA & NA & NCT02644655 \\
\hline CD19 & B cell leukemia and lymphoma & NA & NA & NCT02813837 \\
\hline CD19 & B cell lymphoma & NA & NA & NCT02547948 \\
\hline CD19 & B cell lymphoma & CD28-CD3ろ & RV & NCT02652910 \\
\hline CD19 & Leukemia, lymphoma & CD28, CD3 & LV or RV & NCT02456350 \\
\hline CD19 & $\begin{array}{l}\text { Recurrent or refractory acute } \\
\text { non-T-lymphocyte leukemia }\end{array}$ & NA & NA & NCT02735291 \\
\hline CD19 & Lymphoma & NA & NA & NCT02728882 \\
\hline CD19 & Leukemia, lymphoma & NA & NA & NCT02546739 \\
\hline CD19 & B cell lymphomas & NA & NA & NCT02842138 \\
\hline CD19 & ALL & NA & NA & NCT02810223 \\
\hline CD19 & ALL & CD28-CD137-CD3ろ & LV & NCT02186860 \\
\hline CD19 & B cell leukemia, B cell lymphoma & CD3द, CD28, and 4-1BB & LV & NCT02963038 \\
\hline CD19 & $\mathrm{NHL}$ & $\mathrm{TCR} \zeta, 4-1 \mathrm{BB}$ & LV & NCT03029338 \\
\hline CD19 & B cell ALL & $\mathrm{TCR} \zeta, 4-1 \mathrm{BB}$ & LV & NCT02975687 \\
\hline CD19 & B cell leukemia and lymphoma & NA & LV & NCT02933775 \\
\hline CD19 & B cell leukemia & $4-1 \mathrm{BB}$ & LV & NCT02672501 \\
\hline CD19 & $\begin{array}{l}\text { Central nervous system B cell acute } \\
\text { lymphocytic leukemia }\end{array}$ & NA & NA & NCT03064269 \\
\hline CD19 & ALL & $4-1 \mathrm{BB}$ & LV & NCT02965092 \\
\hline CD19 & Acute leukemia & NA & NA & NCT02822326 \\
\hline CD19 & Leukemia, lymphoma & CD28 or $4-1 B B$ and $a$ CD3ろ & LV or RV & NCT03076437 \\
\hline CD19 & Leukemia and lymphoma & NA & NA & NCT02851589 \\
\hline CD19 & Leukemia and lymphoma & NA & NA & NCT02819583 \\
\hline CD19 & $\mathrm{DLBCL}$ & NA & LV & NCT02976857 \\
\hline CD19 & $\begin{array}{l}\text { Recurrent or refractory B cell } \\
\text { malignancy }\end{array}$ & NA & NA & NCT02782351 \\
\hline CD19 & Leukemia and lymphoma & TCRz-CD28, TCRz-CD137 & NA & NCT02685670 \\
\hline CD19 & B cell lymphoma & 4-1BB, CD3 & NA & NCT03101709 \\
\hline CD19 & ALL & NA & NA & NCT02924753 \\
\hline CD19 & ALL & NA & NA & NCT03027739 \\
\hline CD19 & B cell leukemia & NA & LV & NCT02968472 \\
\hline CD19 & B cell lymphoma & CD28乙 & NA & NCT02992834 \\
\hline CD19 & AML & NA & NA & NCT03018093 \\
\hline CD19 & Systemic lupus erythematosus & $4-1 \mathrm{BB}$ & LV & NCT03030976 \\
\hline CD19 & $\mathrm{NHL}$ & NA & LV & NCT03154775 \\
\hline CD19 & Lymphoma & NA & NA & NCT03086954 \\
\hline
\end{tabular}


Table 2 Clinical trials of CD19-directed CAR-T cells in China (Continued)

\begin{tabular}{|c|c|c|c|c|}
\hline Target antigen & Diseases & CAR & Vector & NCT no. \\
\hline CD19 & ALL, CLL, lymphoma & $\mathrm{CD} 28$ or $4-1 \mathrm{BB}$ and $\mathrm{CD} 3 \zeta$ & NA & NCT03191773 \\
\hline CD19 & B cell lymphoma & 4-1BB-CD28-CD3 & NA & NCT03146533 \\
\hline CD19 & Leukemia & NA & NA & NCT03173417 \\
\hline CD19 & Relapsed or refractory B cell lymphoma & $4-1 \mathrm{BB}$ & LV & NCT03208556 \\
\hline CD19 & B cell leukemia and lymphoma & & & NCT03166878 \\
\hline CD19 & B cell lymphoma & NA & NA & NCT03118180 \\
\hline CD19 or CD20 & Relapse/refractory B cell malignancies & NA & LV & NCT02846584 \\
\hline CD19 and CD20 & DLBCL & NA & NA & NCT02737085 \\
\hline CD19 and CD22 & Hematopoietic/lymphoid cancer & $\mathrm{TCR}, 4-1 \mathrm{BB}$ & NA & NCT02903810 \\
\hline CD19/CD20 & B cell leukemia and lymphoma & $\mathrm{CD} 3 \zeta, 4-1 \mathrm{BB}-\mathrm{CD} 3 \zeta$ & RV & NCT03097770 \\
\hline CD19/CD22 & B cell malignancy & NA & RV & NCT03185494 \\
\hline CD19/CD22 & B cell leukemia, B cell lymphoma & NA & LV & NCT03098355 \\
\hline CD19/CD20/CD22/CD30 & $\mathrm{B}-\mathrm{NHL}$ & NA & NA & NCT03196830 \\
\hline CD19/CD20 & B cell malignancy & NA & NA & NCT03207178 \\
\hline CD19 and CD20/CD22/CD38/CD123 & B cell malignancy & NA & LV & NCT03125577 \\
\hline
\end{tabular}

AMMS Academy Military Medical Sciences, ALL acute lymphoblastic leukemia, $A M L$ acute myeloid leukemia, BCMA B cell maturation antigen, $C T X$ cyclophosphamide, DLBCL diffuse large B cell lymphoma, FLU fludarabine, HL Hodgkin's lymphoma, LV lentiviral, MCL mantle cell lymphoma, NA not available, NHL non-Hodgkin lymphoma, $R V$ retroviral, TCM traditional Chinese medicine

Table 3 Clinical trials of CAR-T cells targeting non-CD19 antigens in China

\begin{tabular}{|c|c|c|c|c|}
\hline Target Antigen & Disease & CAR & Vector & NCT no. \\
\hline $\mathrm{CD} 20$ & Lymphoma & 4-1BB-CD3Z & LV & NCT01735604 \\
\hline CD20 & B cell lymphoma & $\mathrm{CD} 3 \zeta$ and CD28 & RV & NCT02965157 \\
\hline CD20 & B cell malignancies & NA & NA & NCT02710149 \\
\hline CD22 & CD19-refractory or resistant lymphoma & $\mathrm{TCR}$, , 4-1BB & RV & NCT02721407 \\
\hline CD22 & Recurrent or refractory B cell malignancy & NA & NA & NCT02794961 \\
\hline CD22 & B cell malignancies & NA & NA & NCT02935153 \\
\hline CD30 & Lymphoma & NA & LV & NCT02274584 \\
\hline CD30 & $\mathrm{HL}, \mathrm{NHL}$ & NA & NA & NCT02259556 \\
\hline CD30 & Lymphocyte malignancies & NA & NA & NCT02958410 \\
\hline CD33 & AML & 4-1BB-CD3乙 & RV & NCT01864902 \\
\hline CD33 & AML & NA & NA & NCT02799680 \\
\hline CD33 & Myeloid malignancies & NA & NA & NCT02958397 \\
\hline BCMA & B cell malignancies & NA & NA & NCT02954445 \\
\hline BCMA & Multiple myeloma & TCRC, 4-1-BB & RV & NCT03093168 \\
\hline CD123 & Leukemia & NA & NA & NCT02937103 \\
\hline CD123 & AML recurred after allo-HSCT & 41BB-CD3ろ & NA & NCT03114670 \\
\hline CD138 & Multiple myeloma & 4-1BB-CD3 & RV & NCT01886976 \\
\hline CD138/BCMA & Multiple myeloma & NA & NA & NCT03196414 \\
\hline Lewis-Y & Myeloid malignancies & NA & NA & NCT02958384 \\
\hline
\end{tabular}

AMMS Academy of Military Medical Sciences, ALL acute lymphoblastic leukemia, $A M L$ acute myeloid leukemia, $B C M A B$ cell maturation antigen, $C T X$ cyclophosphamide, FLU fludarabine, HL Hodgkin's lymphoma, LV lentiviral, MCL mantle cell lymphoma, NA not available, NHL non-Hodgkin lymphoma, RV retroviral, TCM traditional Chinese medicine 
Table 4 Clinical trials of CAR-T cells for solid tumors in China

\begin{tabular}{|c|c|c|c|c|}
\hline Target antigens & Diseases & CAR & Vector & NCT no. \\
\hline$\overline{\mathrm{GPC} 3}$ & Hepatocellular carcinoma & $\mathrm{NA}$ & NA & NCT02723942 \\
\hline GPC3 & Hepatocellular carcinoma & $\mathrm{CD} 3 \zeta, \mathrm{CD} 28$, and 4-1BB & NA & NCT02395250 \\
\hline GPC3 & Lung squamous cell carcinoma & NA & LV & NCT02876978 \\
\hline GPC3 & Hepatocellular carcinoma and liver metastases & $4-1 B B$ & NA & NCT02715362 \\
\hline GPC3 & Hepatocellular carcinoma & $4-1 \mathrm{BB}$ & NA & NCT03130712 \\
\hline GPC3 & Advanced hepatocellular carcinoma & $4-1 \mathrm{BB}-\mathrm{CD} 3 \zeta$ & RV & NCT03084380 \\
\hline GPC3 & Hepatocellular carcinoma, squamous cell lung cancer & NA & NA & NCT03198546 \\
\hline GPC3 & Hepatocellular carcinoma & NA & LV & NCT03146234 \\
\hline GPC3, mesothelin, CEA & Hepatocellular, pancreatic cancer, colorectal cancer & NA & LV & NCT02959151 \\
\hline Mesothelin & $\begin{array}{l}\text { Malignant mesothelioma, pancreatic Cancer, ovarian } \\
\text { tumor, triple-negative breast cancer, endometrial } \\
\text { cancer, other mesothelin-positive tumors }\end{array}$ & $4-1 \mathrm{BB}-\mathrm{CD} 3 \zeta$ & RV & NCT02580747 \\
\hline Mesothelin & Recurrent or metastatic malignant tumors & NA & NA & NCT02930993 \\
\hline Mesothelin & Pancreatic cancer and pancreatic ductal a denocarcinoma & $4-1 \mathrm{BB}$ & NA & NCT02706782 \\
\hline Mesothelin & Solid tumor, adult advanced cancer & NA & NA & NCT03030001 \\
\hline Mesothelin & Advanced solid tumor & NA & NA & NCT03182803 \\
\hline EpCAM & Liver neoplasms & NA & NA & NCT02729493 \\
\hline EpCAM & Stomach neoplasms & NA & NA & NCT02725125 \\
\hline EpCAM & Nasopharyngeal carcinoma and breast cancer & NA & LV & NCT02915445 \\
\hline EPCAM & $\begin{array}{l}\text { Colon cancer, esophageal carcinoma, pancreatic cancer, } \\
\text { prostate cancer, gastric cancer, hepatic carcinoma }\end{array}$ & $\mathrm{CD} 3 \zeta, \mathrm{CD} 28$ & LV & NCT03013712 \\
\hline GD2 & Neuroblastoma & NA & LV & NCT02765243 \\
\hline GD2 & Relapsed or refractory neuroblastoma & NA & NA & NCT02919046 \\
\hline GD2 & Solid tumor & NA & LV & NCT02992210 \\
\hline HER-2 & Advanced HER-2-positive solid tumors & $\mathrm{CD} 3 \zeta, 4-1 \mathrm{BB}-\mathrm{CD} 3 \zeta$ & NA & NCT01935843 \\
\hline HER-2 & Breast cancer & $\mathrm{CD} 28-\mathrm{CD} 3 \zeta$ & RV & NCT02547961 \\
\hline HER-2 & $\begin{array}{l}\text { Breast cancer, ovarian cancer, lung cancer, gastric cancer, } \\
\text { glioma, pancreatic cancer }\end{array}$ & NA & NA & NCT02713984 \\
\hline EGFR & Advanced EGFR-positive solid tumors & 4-1BB-CD3ろ & LV & NCT01869166 \\
\hline EGFR & Advanced solid tumor & NA & NA & NCT03182816 \\
\hline EGFR & Colorectal cancer & 4-1BB-CD28-CD3 & NA & NCT03152435 \\
\hline EGFRvIII & Recurrent glioblastoma multiform & NA & LV & NCT02844062 \\
\hline EGFRvIII & Glioblastoma multiform & NA & NA & NCT03170141 \\
\hline MUC1 & $\begin{array}{l}\text { Malignant glioma of brain, colorectal carcinoma, gastric } \\
\text { carcinoma }\end{array}$ & NA & NA & NCT02617134 \\
\hline MUC1 & $\begin{array}{l}\text { Advanced refractory solid tumor (hepatocellular carcinoma, } \\
\text { NSCLC, pancreatic carcinoma, triple-negative invasive } \\
\text { breast carcinoma) }\end{array}$ & CD28-4-1BB- CD3ろ & LV & NCT02587689 \\
\hline MUC1 & Advanced solid tumor & NA & NA & NCT03179007 \\
\hline CEA & $\begin{array}{l}\text { Lung cancer, colorectal cancer, gastric cancer, breast } \\
\text { cancer, pancreatic cancer }\end{array}$ & NA & NA & NCT02349724 \\
\hline EphA2 & EphA2-positive malignant glioma & NA & NA & NCT02575261 \\
\hline LMP1 & Nasopharyngeal neoplasms & NA & NA & NCT02980315 \\
\hline MG7 & Liver metastases & $4-1 B B$ & NA & NCT02862704 \\
\hline CD133 & $\begin{array}{l}\text { Liver cancer, pancreatic cancer, brain tumor, breast } \\
\text { cancer, ovarian tumor, colorectal cancer, ALL, AML }\end{array}$ & $\mathrm{CD} 3 \zeta, 4-1 \mathrm{BB}-\mathrm{CD} 3 \zeta$ & RV & NCT02541370 \\
\hline HerinCAR-PD1 & Advanced malignancies & NA & NA & NCT02873390 \\
\hline
\end{tabular}


Table 4 Clinical trials of CAR-T cells for solid tumors in China (Continued)

\begin{tabular}{|c|c|c|c|c|}
\hline Target antigens & Diseases & CAR & Vector & NCT no. \\
\hline HerinCAR-PD1 & Advanced solid tumor (lung, liver, and stomach) & NA & NA & $\overline{\text { NCT02862028 }}$ \\
\hline PD-L1 CSR & Glioblastoma multiform & NA & NA & NCT02937844 \\
\hline NY-ESO-1 & Advanced NSCLC & NA & LV & NCT03029273 \\
\hline Zeushield & NSCLC & NA & NA & NCT03060343 \\
\hline PSCA/MUC1/PD-L1/CD80/86 & Advanced lung or other cancers & NA & NA & NCT03198052 \\
\hline PSMA, FRa & Bladder cancer, urothelial carcinoma bladder & NA & NA & NCT03185468 \\
\hline Claudin 18.2 & $\begin{array}{l}\text { Advanced gastric adenocarcinoma, pancreatic } \\
\text { adenocarcinoma }\end{array}$ & NA & LV & NCT03159819 \\
\hline
\end{tabular}

CTX cyclophosphamide, FLU fludarabine, LV lentiviral, NA not available, NSCLC non-small cell lung cancer, RV retroviral

There are also a few registered clinical trials that are testing two or more CARs either simultaneously or sequentially. In the trial NCT02846584, patients receive intravenously infused autologous anti-CD19 or antiCD20 CAR-T cells to treat B cell malignancies. Another trial, NCT02737085, is to explore the sequential therapeutic effect of anti-CD19 and anti-CD20 CAR-T cells in the treatment of DLBCL.

The trial NCT02903810 was planned with a treatment scheme of infusion of equal numbers of anti-CD19 and anti-CD22 CAR-T cells in the treatment of refractory hematologic malignancies. Two trials (NCT03097770 and NCT03098355) target two antigens simultaneously with one CAR construct (Table 2). These trials are ongoing at this time.

\section{Current trials on solid tumors}

Multiple solid tumors are being studied in CAR-T clinical trials. At the time of this report, 20 different antigens are being targeted in solid tumor trials (Table 4). GPC3, mesothelin, epidermal growth factor receptor (EGFR), and EpCAM were the most targeted antigens (Table 4). This is consistent with reports from international trials [63-68]. Liver cancer remains the most commonly studied solid tumor in China [69]. In a preliminary report of a trial of CAR-T cells against CD133+ epithelial tumors (NCT02541370), 24 patients were enrolled, including 14 patients with sorafenib-refractory hepatocellular carcinoma (HCC), 7 with pancreatic carcinomas, 2 with colorectal carcinomas, and 1 with cholangiocarcinoma [69]. The number of CAR-T cells was found to be inversely related to the CD133+ epithelial cells in peripheral blood. There was a separate report treating refractory cholangiocarcinoma with sequential infusion of two different types of CAR-T cells targeting EGFR and CD133 [70].

Two trials in China are evaluating GD2 antigentargeted CAR-T cells in neuroblastoma (Table 4). Another two trials are evaluating CAR-T cells against EGFRvIII+ glioblastoma. There was one case report in the literature on rapidly progressing refractory glioblastoma that showed dramatic CR to IL13R 2 2-targeted CAR-T cells after repeated infusion [71]. In a separate report, nine patients with refractory EGFRvIII+ glioblastoma received autologous CART-EGFRvIII cells in a pilot study [66]. Interestingly, there was no CRS observed. CAR-T cell infiltration was shown in the resected tumor

Table 5 Clinical trials of CAR-T cells with fourth-generation CARs in China

\begin{tabular}{llll}
\hline Target antigen & Disease & Vector & NCT no. \\
\hline CD19 & B cell malignancies & LV & NCT03050190 \\
CD19 & B cell lymphomas & LV & NCT02247609 \\
CD19 & B cell leukemia & LV & NCT02968472 \\
CD19/CD22 & B cell leukemia, B cell & LV & NCT03098355 \\
CD19 and CD20/CD22/ & B cell malignancy & LV & NCT03125577 \\
CD38/CD123 & Lymphoma & LV & NCT02274584 \\
CD30 & Bladder cancer, urothelial & NA & NCT03185468 \\
PSMA, FRa & carcinoma bladder & NA \\
EGFRVIII & Glioblastoma multiform & LV & NCT03170141 \\
GD2 & Neuroblastoma & LV & NCT02765243 \\
GD2 & Solid tumor & NCT02992210 \\
\hline
\end{tabular}

$L V$ lentiviral vector, $N A$ not available 
specimen. This study suggested that the CAR-T cells are safe and immunologically active with tracking capability to the cancer cells in the brain.

Multiple antigens are being explored as targets in solid tumors for CAR-T cells (Table 4). Preliminary reports have been presented and published throughout the world $[64,65,67,72]$. Outcomes from larger sample size and longer follow-up are clearly needed from these trials.

\section{CAR-T trials for non-malignant diseases}

There is currently one clinical trial of autologous CART19 cells for patients with systemic lupus erythematosus (NCT03030976, Table 2). This trial is designed to infuse $1 \times 10^{6}$ cells $/ \mathrm{kg}$. More trials are expected to come for non-malignant diseases.

\section{Discussion}

This study analyzed CAR-T trials in China. Most CAR-T trials are employing autologous T cells. CD19 is the most commonly targeted antigen. Therefore, B cell leukemia and lymphoma are the most common malignancies in CAR-T trials. Solid tumors remain a significant challenge for CAR$\mathrm{T}$ therapy $[45,70,73,74]$. Challenges include selection of target antigens, management of toxicities, and modulation of tumor microenvironment [75, 76]. Loss of CD19 expression is a known mechanism for relapse from CD19directed CAR-T therapy [77]. The first CAR-T product, tisagenlecleucel, was recently approved. KTE-C19 for large cell lymphoma is under evaluation by FDA $[25,60]$. It is unclear which product among many ongoing clinical CAR$\mathrm{T}$ trials in China has independent patent that may lead to final approval for clinical application in China.

It has been well documented that CAR-T cells can cross the blood-brain barrier [23, 78, 79]. CAR-T cells may become an effective therapy for refractory CNS diseases [66, 71, 78-81]. In addition to trials of singletarget CAR-T cells, simultaneous and sequential CAR-T cells are being studied for clinical applications [70]. Multi-target CAR-engineered $\mathrm{T}$ cells are also entering clinical trials (Tables 2, 3, and 4).

The currently approved tisagenlecleucel CAR-T therapy relies on transduction of autologous $\mathrm{T}$ cells from patients. It is important therefore to be able to reliably obtain and propagate adequate amount of $\mathrm{T}$ cells. This may become a major limitation for wide application of this new therapy. Therefore, newer CARs are being actively investigated [41, 82-84]. Universal CAR-Ts have been generated by inactivating HLA class I molecules and used successfully in patients $[82,85,86]$. Allogeneic CAR-T cells are entering clinical trials [42, 87]. T cell receptor-engineered CAR-T cells represent another frontier in CAR-T cell development [88-90]. It is foreseeable that CAR-T immunotherapy will become a major modality of cancer therapy (Table 5) [91].

\section{Abbreviations}

ALL: Acute lymphoblastic leukemia; AML: Acute myeloid leukemia; BCMA: B cell maturation antigen; CTX: Cyclophosphamide; DLBCL: Diffuse large B cell lymphoma; FLU: Fludarabine; HL: Hodgkin's lymphoma; LV: Lentiviral;

MCL: Mantle cell lymphoma; NHL: Non-Hodgkin lymphoma

\section{Acknowledgements}

This study was partly supported by Henan Cancer Hospital and The Affiliated Cancer Hospital of Zhengzhou University.

\section{Funding}

This project was partly supported by the Zhengzhou University training fellowship (BL) and by the National Natural Science Foundation of China (NSFC grant no. 81470287, YPS). BL is a recipient of the 2017 CAHON Young Investigator Award (www.cahon.org).

\section{Availability of data and materials}

The material supporting the conclusion of this study has been included within the article.

\section{Authors' contributions}

$\mathrm{DL}$ designed the study. All authors drafted the manuscript. All authors read and approved final manuscript.

Ethics approval and consent to participate

This is not applicable for this study.

\section{Consent for publication}

This is not applicable for this study.

\section{Competing interests}

The authors declare that they have no competing interests.

\section{Author details}

${ }^{1}$ School of Basic Medical Sciences and The Affiliated Cancer Hospital of Zhengzhou University, Zhengzhou, China. ${ }^{2}$ Henan Cancer Hospital and The Affiliated Cancer Hospital of Zhengzhou University, 127 Dongming Road, Zhengzhou 450008, China.

Received: 10 September 2017 Accepted: 13 October 2017

Published online: 23 October 2017

\section{References}

1. Brahmer J, Reckamp KL, Baas P, Crino L, Eberhardt WE, Poddubskaya E, Antonia S, Pluzanski A, Vokes EE, Holgado E, Waterhouse D, Ready N, Gainor J, Aren Frontera O, Havel L, Steins M, Garassino MC, Aerts JG, Domine M, Paz-Ares L, Reck M, Baudelet C, Harbison CT, Lestini B, Spigel DR. Nivolumab versus docetaxel in advanced squamous-cell non-small-cell lung cancer. $\mathrm{N}$ Engl J Med. 2015;373(2):123-35.

2. Brahmer JR, Tykodi SS, Chow LQ, Hwu WJ, Topalian SL, Hwu P, Drake CG, Camacho LH, Kauh J, Odunsi K, Pitot HC, Hamid O, Bhatia S, Martins R, Eaton K, Chen S, Salay TM, Alaparthy S, Grosso JF, Korman AJ, Parker SM, Agrawal S, Goldberg SM, Pardoll DM, Gupta A, Wigginton JM. Safety and activity of anti-PD-L1 antibody in patients with advanced cancer. N Engl J Med. 2012;366(26):2455-65.

3. Lee $\mathrm{CH}$, Motzer RJ. Immune checkpoint therapy in renal cell carcinoma. Cancer J. 2016;22(2):92-5.

4. Lee CK, Man J, Lord S, Links M, Gebski V, Mok T, Yang JC. Checkpoint inhibitors in metastatic EGFR-mutated non-small cell lung cancer-a metaanalysis. J Thorac Oncol. 2017;12(2):403-7.

5. Lee JY, Lee HT, Shin W, Chae J, Choi J, Kim SH, Lim H, Won Heo T, Park KY, Lee YJ, Ryu SE, Son JY, Lee JU, Heo YS. Structural basis of checkpoint blockade by monoclonal antibodies in cancer immunotherapy. Nat Commun. 2016;7:13354.

6. Tumeh $\mathrm{PC}$, Harview $\mathrm{CL}$, Yearley $\mathrm{JH}$, Shintaku IP, Taylor EJ, Robert L, Chmielowski B, Spasic M, Henry G, Ciobanu V, West AN, Carmona M, Kivork C, Seja E, Cherry G, Gutierrez AJ, Grogan TR, Mateus C, Tomasic G, Glaspy JA Emerson RO, Robins H, Pierce RH, Elashoff DA, Robert C, Ribas A. PD-1 blockade induces responses by inhibiting adaptive immune resistance. Nature. 2014;515(7528):568-71. 
7. Ribas A. Releasing the brakes on cancer immunotherapy. N Engl J Med. 2015;373(16):1490-2.

8. Davar D, Socinski MA, Dacic S, Burns TF. Near complete response after single dose of nivolumab in patient with advanced heavily pre-treated KRAS mutant pulmonary adenocarcinoma. Exp Hematol Oncol. 2015;4:34.

9. Dholaria B, Hammond W, Shreders A, Lou Y. Emerging therapeutic agents for lung cancer. J Hematol Oncol. 2016;9:138.

10. Falchi L, Sawas A, Deng C, Amengual JE, Colbourn DS, Lichtenstein EA, Khan KA, Schwartz LH, O'Connor OA. High rate of complete responses to immune checkpoint inhibitors in patients with relapsed or refractory Hodgkin lymphoma previously exposed to epigenetic therapy. J Hematol Oncol. 2016;9(1):132.

11. Hsueh EC, Gorantla KC. Novel melanoma therapy. Exp Hematol Oncol. 2016;5(1):23.

12. Kaufman HL, Russell J, Hamid O, Bhatia S, Terheyden P, D'Angelo SP, Shih KC, Lebbé C, Linette GP, Milella M, Brownell I, Lewis KD, Lorch JH, Chin K, Mahnke L, von Heydebreck A, Cuillerot J-M, Nghiem P. Avelumab in patients with chemotherapy-refractory metastatic Merkel cell carcinoma: a multicentre, single-group, open-label, phase 2 trial. Lancet Oncol. 2016; 17(10):1374-85.

13. Baron F, Labopin M, Ruggeri A, Mohty M, Sanz G, Milpied N, Bacigalupo A, Rambaldi A, Bonifazi F, Bosi A, Sierra J, Yakoub-Agha I, Santasusana JM, Gluckman E, Nagler A. Unrelated cord blood transplantation for adult patients with acute myeloid leukemia: higher incidence of acute graftversus-host disease and lower survival in male patients transplanted with female unrelated cord blood_-a report from Eurocord, the Acute Leukemia Working Party, and the Cord Blood Committee of the Cellular Therapy and Immunobiology Working Party of the European Group for Blood and Marrow Transplantation. J Hematol Oncol. 2015;8:107.

14. Baron F, Lechanteur C, Willems E, Bruck F, Baudoux E, Seidel L. Cotransplantation of mesenchymal stem cells might prevent death from graftversus-host disease (GVHD) without abrogating graft-versus-tumor effects after HLA-mismatched allogeneic transplantation following nonmyeloablative conditioning. Biol Blood Marrow Transplant. 2010;16:838-47.

15. Baron F, Zachee P, Maertens J, Kerre T, Ory A, Seidel L, Graux C, Lewalle P, Van Gelder M, Theunissen K, Willems E, Emonds M-P, De Becker A, Beguin Y. Non-myeloablative allogeneic hematopoietic cell transplantation following fludarabine plus 2Gy TBI or ATG plus 8Gy TLI: a phase II randomized study from the Belgian Hematological Society. J Hematol Oncol. 2015;8:4.

16. Gooley TA, Chien JW, Pergam SA, Hingorani S, Sorror ML, Boeckh M, Martin PJ, Sandmaier BM, Marr KA, Appelbaum FR, Storb R, McDonald GB. Reduced mortality after allogeneic hematopoietic-cell transplantation. N Engl J Med. 2010;363(22):2091-101

17. Gragert L, Eapen M, Williams E, Freeman J, Spellman S, Baitty R, Hartzman R, Rizzo JD, Horowitz M, Confer D, Maiers M. HLA match likelihoods for hematopoietic stem-cell grafts in the U.S. Registry. N Engl J Med. 2014;371(4):339-48.

18. Koreth J, Matsuoka K, Kim HT, SM MD, Bindra B, EPI A, Armand P, Cutler C, Ho VT, Treister NS, Bienfang DC, Prasad S, Tzachanis D, Joyce RM, Avigan $\mathrm{DE}$, Antin JH, Ritz J, Soiffer RJ. Interleukin-2 and regulatory T cells in graftversus-host disease. N Engl J Med. 2011:365(22):2055-66

19. Kalos M, Levine BL, Porter DL, Katz S, Grupp SA, Bagg A, June CH. T cells with chimeric antigen receptors have potent antitumor effects and can establish memory in patients with advanced leukemia. Sci Transl Med. 2011;3(95):95ra73.

20. Barrett DM, Liu X, Jiang S, June CH, Grupp SA, Zhao Y. Regimen-specific effects of RNA-modified chimeric antigen receptor $T$ cells in mice with advanced leukemia. Hum Gene Ther. 2013;24(8):717-27.

21. Grupp SA, Kalos M, Barrett D, Aplenc R, Porter DL, Rheingold SR, Teachey DT, Chew A, Hauck B, Wright JF, Milone MC, Levine BL, June CH. Chimeric antigen receptor-modified T cells for acute lymphoid leukemia. N Engl J Med. 2013:368(16):1509-18

22. Porter DL, Hwang WT, Frey NV, Lacey SF, Shaw PA, Loren AW, Bagg A, Marcucci KT, Shen A, Gonzalez V, Ambrose D, Grupp SA, Chew A, Zheng Z, Milone MC, Levine BL, Melenhorst JJ, June CH. Chimeric antigen receptor T cells persist and induce sustained remissions in relapsed refractory chronic lymphocytic leukemia. Sci Transl Med. 2015;7(303):303ra139.

23. Porter DL, Levine BL, Kalos M, Bagg A, June CH. Chimeric antigen receptormodified T cells in chronic lymphoid leukemia. N Engl J Med. 2011;365(8):725-33.

24. Porter DL, Kalos M, Zheng Z, Levine B, June C. Chimeric antigen receptor therapy for B-cell malignancies. J Cancer. 2011;2:331-2.

25. Locke FL, Neelapu SS, Bartlett NL, Siddiqi T, Chavez JC, Hosing CM, Ghobadi A, Budde LE, Bot A, Rossi JM, Jiang Y, Xue AX, Elias M, Aycock J, Wiezorek J,
Go WY. Phase 1 results of ZUMA-1: a multicenter study of KTE-C19 antiCD19 CAR T cell therapy in refractory aggressive lymphoma. Mol Ther. 2017;25(1):285-95

26. Turtle CJ, Riddell SR, Maloney DG. CD19-targeted chimeric antigen receptormodified T-cell immunotherapy for B-cell malignancies. Clin Pharmacol Ther. 2016;100(3):252-8.

27. Turtle C, Maloney DG. Clinical trials of CD19-targeted CAR-modified T cell therapy; a complex and varied landscape. Expert Rev Hematol. 2016;9(8):719-21.

28. Ruella M, Kenderian SS, Shestova O, Fraietta JA, Qayyum S, Zhang Q, Maus MV, Liu X, Nunez-Cruz S, Klichinsky M, Kawalekar OU, Milone M, Lacey SF, Mato A, Schuster SJ, Kalos M, June CH, Gill S, Wasik MA. The addition of the BTK inhibitor ibrutinib to anti-CD19 chimeric antigen receptor T cells (CART19) improves responses against mantle cell lymphoma. Clin Cancer Res. 2016;22(11):2684-96.

29. Park JH, Brentjens RJ. Adoptive immunotherapy for B-cell malignancies with autologous chimeric antigen receptor modified tumor targeted T cells. Discov Med. 2010;9(47):277-88,

30. Wei G, Ding L, Wang J, Hu Y, Huang H. Advances of CD19-directed chimeric antigen receptor-modified $T$ cells in refractory/relapsed acute lymphoblastic leukemia. Exp Hematol Oncol. 2017;6(1):10.

31. Perez-Ruiz E, Etxeberria I, Rodriguez-Ruiz ME, Melero I. Anti-CD137 and PD1/PD-L1 antibodies en route toward clinical synergy. Clin Cancer Res. 2017; 23(18):5326-28. doi:10.1158/1078-0432.CCR-17-1799. Epub 2017 Aug 8.

32. Park JH, Brentjens RJ. Are all chimeric antigen receptors created equal? J Clin Oncol. 2015;33(6):651-3.

33. Brentjens RJ. Are chimeric antigen receptor T cells ready for prime time? Clin Adv Hematol Oncol. 2016;14(1):17-9.

34. Wang CM, Wu ZQ, Wang Y, Guo YL, Dai HR, Wang XH, Li X, Zhang YJ, Zhang WY, Chen MX, Zhang Y, Feng KC, Liu Y, Li SX, Yang QM, Han WD. Autologous T cells expressing CD30 Chimeric antigen receptors for relapsed or refractory Hodgkin lymphoma: an open-label phase I trial. Clin Cancer Res. 2017;23(5):1156-66.

35. Sadelain M, Brentjens R, Riviere I. The basic principles of chimeric antigen receptor design. Cancer Discov. 2013;3(4):388-98.

36. Sadelain M, Brentjens R, Riviere I, Park J. CD19 CAR therapy for acute lymphoblastic leukemia. Am Soc Clin Oncol Educ Book. 2015:e360-3. doi:10.14694/EdBook_AM.2015.35.e360.

37. Davila ML, Brentjens RJ. CD19-targeted CAR T cells as novel cancer immunotherapy for relapsed or refractory B-cell acute lymphoblastic leukemia. Clin Adv Hematol Oncol. 2016;14(10):802-8.

38. Garfall AL, Maus MV, Hwang WT, Lacey SF, Mahnke YD, Melenhorst JJ, Zheng Z, Vogl DT, Cohen AD, Weiss BM, Dengel K, Kerr ND, Bagg A, Levine BL, June $\mathrm{CH}$, Stadtmauer EA. Chimeric antigen receptor T cells against CD19 for multiple myeloma. N Engl J Med. 2015;373(11):1040-7.

39. Li Z, Liu D. Cell therapy must be regulated as medicine. Exp Hematol Oncol. 2016:5(1):26.

40. Batlevi CL, Matsuki E, Brentjens RJ, Younes A. Novel immunotherapies in lymphoid malignancies. Nat Rev Clin Oncol. 2016;13(1):25-40.

41. Zhang C, Liu J, Zhong JF, Zhang X. Engineering CAR-T cells. Biomark Res. 2017:5(1):22.

42. Cai B, Guo M, Wang Y, Zhang Y, Yang J, Guo Y, Dai H, Yu C, Sun Q, Qiao J Hu K, Zuo H, Dong Z, Zhang Z, Feng M, Li B, Sun Y, Liu T, Liu Z, Wang Y, Huang Y, Yao B, Han W, Ai H. Co-infusion of haplo-identical CD19-chimeric antigen receptor $T$ cells and stem cells achieved full donor engraftment in refractory acute lymphoblastic leukemia. J Hematol Oncol. 2016;9(1):131.

43. Fan $D$, Li Z, Zhang $X$, Yang $Y$, Yuan $X$, Zhang $X$, Yang $M$, Zhang $Y$, Xiong D. AntiCD3Fv fused to human interleukin-3 deletion variant redirected T cells against human acute myeloid leukemic stem cells. J Hematol Oncol. 2015;8(1):18

44. Nakazawa Y, Matsuda K, Kurata T, Sueki A, Tanaka M, Sakashita K, Imai C, Wilson MH, Koike K. Anti-proliferative effects of T cells expressing a ligandbased chimeric antigen receptor against CD116 on CD34+ cells of juvenile myelomonocytic leukemia. J Hematol Oncol. 2016;9(1):27.

45. Song D-G, Ye Q, Poussin M, Chacon JA, Figini M, Powell DJ. Effective adoptive immunotherapy of triple-negative breast cancer by folate receptor-alpha redirected CAR T cells is influenced by surface antigen expression level. J Hematol Oncol. 2016;9(1):56.

46. Sanmamed MF, Pastor F, Rodriguez A, Perez-Gracia JL, Rodriguez-Ruiz ME, Jure-Kunkel M, Melero I. Agonists of co-stimulation in cancer immunotherapy directed against CD137, OX40, GITR, CD27, CD28, and ICOS Semin Oncol. 2015;42(4):640-55. 
47. Milone MC, Fish JD, Carpenito C, Carroll RG, Binder GK, Teachey D, Samanta M, Lakhal M, Gloss B, Danet-Desnoyers G, Campana D, Riley JL, Grupp SA, June $\mathrm{CH}$. Chimeric receptors containing CD137 signal transduction domains mediate enhanced survival of T cells and increased antileukemic efficacy in vivo. Mol Ther. 2009;17(8):1453-64.

48. Song DG, Ye Q, Poussin M, Harms GM, Figini M, Jr Powell DJ. CD27 costimulation augments the survival and antitumor activity of redirected human T cells in vivo. Blood. 2012;119(3):696-706.

49. Srivastava RM, Trivedi S, Concha-Benavente F, Gibson SP, Reeder C, Ferrone S, Ferris RL. CD137 stimulation enhances cetuximab-induced natural killer: dendritic cell priming of antitumor T-cell immunity in patients with head and neck cancer. Clin Cancer Res. 2017;23(3):707-16.

50. Tolcher AW, Sznol M, Hu-Lieskovan S, Papadopoulos KP, Patnaik A, Rasco DW, Di Gravio D, Huang B, Gambhire D, Chen Y, Thall AD, Pathan N, Schmidt EV, Chow LQM. Phase lb study of Utomilumab (PF-05082566), a 41BB/CD137 agonist, in combination with pembrolizumab (MK-3475) in patients with advanced solid tumors. Clin Cancer Res. 2017;23(18):5349-57. doi: 10.1158/1078-0432.CCR-17-1243. Epub 2017 Jun 20.

51. Metzger TC, Long H, Potluri S, Pertel T, Bailey-Bucktrout SL, Lin JC, Fu T, Sharma P, Allison JP, Feldman RM. ICOS promotes the function of CD4+ effector T cells during anti-OX40-mediated tumor rejection. Cancer Res. 2016;76(13):3684-9.

52. Aspeslagh S, Postel-Vinay S, Rusakiewicz S, Soria JC, Zitvogel L, Marabelle A. Rationale for anti-OX40 cancer immunotherapy. Eur J Cancer. 2016;52:50-66.

53. Budde LE, Berger C, Lin Y, Wang J, Lin X, Frayo SE, Brouns SA, Spencer DM, Till BG, Jensen MC, Riddell SR, Press OW. Combining a CD20 chimeric antigen receptor and an inducible caspase 9 suicide switch to improve the efficacy and safety of $\mathrm{T}$ cell adoptive immunotherapy for lymphoma. PLoS One. 2013;8(12):e82742.

54. Maude SL, Frey N, Shaw PA, Aplenc R, Barrett DM, Bunin NJ, Chew A, Gonzalez VE, Zheng Z, Lacey SF, Mahnke YD, Melenhorst JJ, Rheingold SR, Shen A, Teachey DT, Levine BL, June CH, Porter DL, Grupp SA. Chimeric antigen receptor T cells for sustained remissions in leukemia. N Engl J Med. 2014;371(16):1507-17.

55. Schuster SJ, Svoboda J, Nasta SD, Chong EA, Winchell N, Landsburg DJ, Porter DL, Mato AR, Strauser HT, Schrank-Hacker AM, Wasik MA, Lacey SF, Melenhorst JJ, Chew A, Hasskarl J, Marcucci KT, Levine BL, June $\mathrm{CH}$. Treatment with chimeric antigen receptor modified $T$ cells directed against CD19 (CTL019) results in durable remissions in patients with relapsed or refractory diffuse large $B$ cell lymphomas of germinal center and non-germinal center origin, "double hit" diffuse large B cell lymphomas, and transformed follicular to diffuse large B cell lymphomas. Blood. 2016;128(22):3026.

56. Xiao L, Huang H, Huang X, Ke X, Hu Y, Li J, Zhang Q, Hu Y, Jiang Q, Hu J, Jing $H$, Zhang $X$, Wu Z. Efficacy of anti-CD19 chimeric antigen receptor modified T(CAR-T) cell therapy in Chinese patients with relapsed/refractory acute lymphocytic leukemia in a multicenter trial. J Clin Oncol. 2017;35(15_suppl):7028.

57. Brentjens RJ, Davila ML, Riviere I, Park J, Wang X, Cowell LG, Bartido S, Stefanski J, Taylor C, Olszewska M, Borquez-Ojeda O, Qu J, Wasielewska T, He Q, Bernal Y, Rijo IV, Hedvat C, Kobos R, Curran K, Steinherz P, Jurcic J, Rosenblat T, Maslak P, Frattini M, Sadelain M. CD19-targeted T cells rapidly induce molecular remissions in adults with chemotherapy-refractory acute lymphoblastic leukemia. Sci Transl Med. 2013;5(177):177ra138.

58. Park JH, Geyer MB, Brentjens RJ. CD19-targeted CAR T-cell therapeutics for hematologic malignancies: interpreting clinical outcomes to date. Blood. 2016;127(26):3312-20.

59. Park JH, Riviere I, Wang X, Senechal B, Wang Y, Mead E, Santomasso B, Halton E, Diamonte C, Bernal Y, Li D, Sadelain M, Brentjens RJ. Durable longterm survival of adult patients with relapsed B-ALL after CD19 CAR (19-28z) T-cell therapy. J Clin Oncol. 2017;35(15_suppl):7008.

60. Neelapu SS, Locke FL, Bartlett NL, Lekakis L, Miklos D, Jacobson CA, Braunschweig I, Oluwole O, Siddiqi T, Lin Y, Timmerman J, Stiff PJ, Friedberg J, Flinn I, Goy A, Smith M, Deol A, Farooq U, McSweeney P, Munoz J, Avivi I, Castro JE, Westin JR, Chavez JC, Ghobadi A, Komanduri KV, Levy R, Jacobsen ED, Reagan P, Bot A, et al. Kte-C19 (anti-CD19 CAR T cells) induces complete remissions in patients with refractory diffuse large B-cell lymphoma (DLBCL): results from the pivotal phase 2 Zuma-1. Blood. 2016;128(22):LBA-6.

61. Fan F, Zhao W, Liu J, He A, Chen Y, Cao X, Yang N, Wang B, Zhang P, Zhang Y, Wang F, Lei B, Gu L, Wang X, Zhuang Q, Zhang W. Durable remissions with BCMA-specific chimeric antigen receptor (CAR)-modified T cells in patients with refractory/relapsed multiple myeloma. J Clin Oncol. 2017;35(18_suppl):LBA3001.

62. Garfall AL, Stadtmauer EA, June $\mathrm{CH}$. Chimeric antigen receptor T cells in myeloma. N Engl J Med. 2016;374(2):194.
63. Koneru M, O'Cearbhaill R, Pendharkar S, Spriggs DR, Brentjens RJ. A phase I clinical trial of adoptive T cell therapy using IL-12 secreting MUC-16(ecto) directed chimeric antigen receptors for recurrent ovarian cancer. J Transl Med. 2015;13:102.

64. Ahmed N, Brawley VS, Hegde M, Robertson C, Ghazi A, Gerken C, Liu E, Dakhova O, Ashoori A, Corder A, Gray T, Wu M-F, Liu H, Hicks J, Rainusso N, Dotti G, Mei Z, Grilley B, Gee A, Rooney CM, Brenner MK, Heslop HE, Wels WS, Wang LL, Anderson P, Gottschalk S. Human epidermal growth factor receptor 2 (HER2)-specific chimeric antigen receptor-modified T cells for the immunotherapy of HER2-positive sarcoma. J Clin Oncol. 2015;33(15):1688-96.

65. Hassan R, Thomas A, Alewine C, Le DT, Jaffee EM, Pastan I. Mesothelin immunotherapy for cancer: ready for prime time? J Clin Oncol. 2016;34(34):4171-9.

66. O'Rourke DM, Nasrallah M, Morrissette JJ, Melenhorst JJ, Lacey SF, Mansfield K, Martinez-Lage M, Desai AS, Brem S, Maloney E, Mohan S, Wang S, Verma G, Navenot J-M, Shen A, Zheng Z, Levine B, Okada H, June CH, Maus MV. Pilot study of $T$ cells redirected to EGFRvIll with a chimeric antigen receptor in patients with EGFRvIll+ glioblastoma. J Clin Oncol. 2016;34(15_suppl):2067.

67. Yeku OO, Purdon T, Spriggs DR, Brentjens RJ. Chimeric antigen receptor (CAR) T cells genetically engineered to deliver IL-12 to the tumor microenvironment in ovarian cancer. J Clin Oncol. 2017;35(15_suppl): 3050.

68. Hegde M, Wakefield A, Brawley VS, Grada Z, Byrd TT, Chow KK, Krebs SS, Heslop HE, Gottschalk SM, Yvon E, Ahmed N. Genetic modification of T cells with a novel bispecific chimeric antigen receptor to enhance the control of high-grade glioma (HGG). J Clin Oncol. 2014;32(15_suppl):10027.

69. Wang Y, Chen M, Wu Z, Tong C, Huang J, Lv H, Dai H, Feng K, Guo Y, Liu Y, Yang Q, Han W. CD133-redirected chimeric antigen receptor engineered autologous T-cell treatment in patients with advanced and metastatic malignancies. J Clin Oncol. 2017;35(15_suppl):3042.

70. K-c F, Guo Y-I, Liu Y, Dai HR, Wang Y, Lv HY, Huang JH, Yang QM, Han WD. Cocktail treatment with EGFR-specific and CD133-specific chimeric antigen receptor-modified $T$ cells in a patient with advanced cholangiocarcinoma. J Hematol Oncol. 2017;10(1):4.

71. Brown CE, Alizadeh D, Starr R, Weng L, Wagner JR, Naranjo A, Ostberg JR, Blanchard MS, Kilpatrick J, Simpson J, Kurien A, Priceman SJ, Wang X, Harshbarger TL, D'Apuzzo M, Ressler JA, Jensen MC, Barish ME, Chen M, Portnow J, Forman SJ, Badie B. Regression of Glioblastoma after chimeric antigen receptor T-cell therapy. N Engl J Med. 2016; 375(26):2561-9.

72. You F, Jiang L, Zhang B, Lu Q, Zhou Q, Liao X, Wu H, Du K, Zhu Y, Meng H, Gong Z, Zong Y, Huang L, Lu M, Tang J, Li Y, Zhai X, Wang X, Ye S, Chen D, Yuan L, Qi L, Yang L. Phase 1 clinical trial demonstrated that MUC1 positive metastatic seminal vesicle cancer can be effectively eradicated by modified anti-MUC1 chimeric antigen receptor transduced T cells. Sci China Life Sci. 2016:59(4):386-97.

73. Feng K, Guo Y, Dai H, Wang Y, Li X, Jia H, Han W. Chimeric antigen receptor-modified $T$ cells for the immunotherapy of patients with EGFRexpressing advanced relapsed/refractory non-small cell lung cancer. Sci China Life Sci. 2016:59(5):468-79.

74. Jin L, Ge H, Long Y, Yang C, Chang YE, Mu L, Sayour EJ, De Leon G, Wang QJ, Yang JC, Kubilis PS, Bao H, Xia S, Lu D, Kong Y, Hu L, Shang Y, Jiang C, Nie J, Li S, Gu Y, Sun J, Mitchell DA, Lin Z, Huang J. CD70, a novel target of CAR-T-cell therapy for gliomas. Neuro-Oncology. 2017;19 doi:10.1093/ neuonc/nox116.

75. Barrett DM, Singh N, Porter DL, Grupp SA, June $\mathrm{CH}$. Chimeric antigen receptor therapy for cancer. Annu Rev Med. 2014;65:333-47.

76. Bonifant $\mathrm{CL}$, Jackson HJ, Brentjens RJ, Curran KJ. Toxicity and management in CAR T-cell therapy. Mol Ther Oncolytics. 2016;3:16011.

77. Gardner R, Wu D, Cherian S, Fang M, Hanafi LA, Finney O, Smithers H, Jensen MC, Riddell SR, Maloney DG, Turtle CJ. Acquisition of a CD19negative myeloid phenotype allows immune escape of MLL-rearranged BALL from CD19 CAR-T-cell therapy. Blood. 2016;127(20):2406-10.

78. Hu Y, Sun J, Wu Z, Yu J, Cui Q, Pu C, Liang B, Luo Y, Shi J, Jin A, Xiao L, Huang $\mathrm{H}$. Predominant cerebral cytokine release syndrome in CD19directed chimeric antigen receptor-modified T cell therapy. J Hematol Oncol. 2016;9(1):70.

79. Abramson JS, McGree B, Noyes S, Plummer S, Wong C, Chen Y-B, Palmer E, Albertson T, Ferry JA, Arrillaga-Romany IC. Anti-CD19 CAR T cells in CNS diffuse large-B-cell lymphoma. N Engl J Med. 2017;377(8):783-4.

80. Turtle CJ, Hanafi LA, Berger C, Hudecek M, Pender B, Robinson E, Hawkins R, Chaney C, Cherian S, Chen X, Soma L, Wood B, Li D, Heimfeld S, Riddell SR, 
Maloney DG. Immunotherapy of non-Hodgkin's lymphoma with a defined ratio of CD8+ and CD4+ CD19-specific chimeric antigen receptor-modified T cells. Sci Transl Med. 2016;8(355):355ra116.

81. Turtle CJ, Hanafi LA, Berger C, Gooley TA, Cherian S, Hudecek M, Sommermeyer D, Melville K, Pender B, Budiarto TM, Robinson E, Steevens NN, Chaney C, Soma L, Chen X, Yeung C, Wood B, Li D, Cao J, Heimfeld S, Jensen MC, Riddell SR, Maloney DG. CD19 CAR-T cells of defined CD4+:CD8+ composition in adult B cell ALL patients. J Clin Invest. 2016;126(6):2123-38.

82. Ren J, Liu X, Fang $C$, Jiang $S$, June $C H$, Zhao Y. Multiplex genome editing to generate universal CAR T cells resistant to PD1 inhibition. Clin Cancer Res. 2017:23(9):2255-66.

83. Kebriaei $P$, Singh $H$, Huls MH, Figliola MJ, Bassett R, Olivares S, Jena B, Dawson MJ, Kumaresan PR, Su S, Maiti S, Dai J, Moriarity B, Forget MA Senyukov V, Orozco A, Liu T, McCarty J, Jackson RN, Moyes JS, Rondon G, Qazilbash M, Ciurea S, Alousi A, Nieto Y, Rezvani K, Marin D, Popat U, Hosing C, Shpall EJ, et al. Phase I trials using sleeping beauty to generate CD19specific CAR T cells. J Clin Invest. 2016;126(9):3363-76.

84. Kunert A, Straetemans T, Govers C, Lamers C, Mathijssen R, Sleijfer S, Debets R. TCR-engineered T cells meet new challenges to treat solid tumors: choice of antigen, T cell fitness, and sensitization of tumor milieu. Front Immunol. 2013;4:363.

85. Qasim W, Zhan H, Samarasinghe S, Adams S, Amrolia P, Stafford S, Butler K, Rivat C, Wright G, Somana K, Ghorashian S, Pinner D, Ahsan G, Gilmour K, Lucchini G, Inglott S, Mifsud W, Chiesa R, Peggs KS, Chan L, Farzeneh F, Thrasher AJ, Vora A, Pule M, Veys P. Molecular remission of infant B-ALL after infusion of universal TALEN gene-edited CAR T cells. Sci Transl Med. 2017;9(374): 10.1126/scitransImed.aaj2013.

86. Barrett DM, Grupp SA, June CH. Chimeric antigen receptor- and TCR-modified T cells enter main street and wall street. J Immunol. 2015;195(3):755-61.

87. Brudno JN, RPT S, Shi V, Rose JJ, Halverson DC, Fowler DH, Gea-Banacloche JC, Pavletic SZ, Hickstein DD, Lu TL, Feldman SA, Iwamoto AT, Kurlander R, Maric I, Goy A, Hansen BG, Wilder JS, Blacklock-Schuver B, Hakim FT, Rosenberg SA, Gress RE, Kochenderfer JN. Allogeneic T cells that express an anti-CD19 chimeric antigen receptor induce remissions of B-cell malignancies that progress after allogeneic hematopoietic stem-cell transplantation without causing graft-versus-host disease. J Clin Oncol. 2016:34(10):1112.

88. Debets R, Donnadieu E, Chouaib S, Coukos G. TCR-engineered T cells to treat tumors: seeing but not touching? Semin Immunol. 2016;28(1):10-21.

89. Ping Y, Liu C, Zhang Y. T-cell receptor-engineered T cells for cancer treatment: current status and future directions. Protein Cell. 2017;8 https:// doi.org/10.1007/s13238-016-0367-1.

90. Rapoport AP, Stadtmauer EA, Binder-Scholl GK, Goloubeva O, Vogl DT, Lacey SF, Badros AZ, Garfall A, Weiss B, Finklestein J, Kulikovskaya I, Sinha SK, Kronsberg S, Gupta M, Bond S, Melchiori L, Brewer JE, Bennett AD, Gerry AB, Pumphrey NJ, Williams D, Tayton-Martin HK, Ribeiro L, Holdich T, Yanovich S, Hardy N, Yared J, Kerr N, Philip S, Westphal S, et al. NY-ESO-1-specific TCRengineered $\mathrm{T}$ cells mediate sustained antigen-specific antitumor effects in myeloma. Nat Med. 2015;21(8):914-21.

91. Rosenbaum L. Tragedy, perseverance, and chance-the story of CAR-T therapy. N Engl J Med. 2017;377(0): 10.1056/NEJMp1711886.

\section{Submit your next manuscript to BioMed Central and we will help you at every step:}

- We accept pre-submission inquiries

- Our selector tool helps you to find the most relevant journal

- We provide round the clock customer support

- Convenient online submission

- Thorough peer review

- Inclusion in PubMed and all major indexing services

- Maximum visibility for your research

Submit your manuscript at www.biomedcentral.com/submit
Biomed Central 